Оригинални научни рад

УДК 811.131.1'367

821.131.1.09-96 Galilej G.

Примљен: 30. марта 2021.

Прихваћен: 23. априла 2021.

Јелена Р. Дрљевић ${ }^{1}$

https://doi.org/10.46630/phm.13.2021.44

Универзитет у Београду

Филолошки факултет

Катедра за италијанистику

\title{
КОМУНИКАТИВНА ФУНКЦИЈА УМЕТНУТИХ РЕЧЕНИЦА У ДЕЛУ DIALOGO SOPRA I DUE MASSIMI SISTEMI DEL MONDO² ГАЛИЛЕА ГАЛИЛЕЈА
}

У раду анализирамо комуникативну функцију уметнутих реченица које су у великој мери присутне у делу Дијалог о два главна система света италијанског научника Галилеа Галилеја. Осим изузетне важности овог дела за науку, оно представља репрезентативни пример коришћења народног језика у функцији исказивања научних знања и тиме даљој дифузији науке. У том смислу, синтакса чини посебно упечатљив језички ниво. Писац синтаксу у знатној мери реорганизује и кодификује, повећавајући фреквентност појединих елемената који су се до XVII века слабо користили. Наш циљ је да покажемо како један синтаксички елемент - уметнута реченица - доприноси комуникацији између научника и публике, утичући на тај начин директно и на разумљивост научног садржаја. Истраживање функција овог специфично употребљеног синтаксичког елемента сагледаћемо у ширем контексту дијалошког жанра чију динамичност Галилеј користи за представљање својих, а тиме и модерних научних ставова и сазнања, надовезујући се, али и надограђујући ову античку прозну форму, посебно прикладну за језичко експериментисање.

Клучне речи: уметнуте реченице, Галилео Галилеј, дијалог, синтакса, комуникативна функција

\section{1. Увод}

Када се поведе дискусија о научним достигнућима и сазнањима до којих је крајем XVI и у XVII веку дошао Галилео Галилеј научна јавност је сложна у закључку да овог италијанског великана треба узети за зачетника модерне научне мисли. Галилеј је промишљао и стварао у

1 drljevic@fil.bg.ac.rs

2 У преводу Саше Хрњеза из 2012. године Дијалог о два главна система света. Овај превод наслова дела користићемо и у нашем раду. 
историјском контексту и времену који су налагали револуционарне научне постулате и критеријуме, уз прихватање концепта математизације природе. Нови концепт је подразумевао мењање улоге математике у схватању природе, те она од инструмента који је служио за предвиђање природних феномена постаје инструмент за описивање суштинске природе ствари (ĐUDIČE).

С друге стране, оно што језичке стручњаке у највећој мери фасцинира, пре свега ауторе који су изучавали и изучавају историјски развој италијанског језика, с посебним освртом на развој језика науке, јесте изузетан Галилејев таленат за писање и вештина да сувопарном научном дискурсу подари литерарни тон, и тиме оствари везу са широм читалачком публиком. Један је од ретких научника, како подвлачи Алтијери Бијаџи (Altieri Biagi) за кога је књижевна критика константно била и јесте заинтересована (ALTIJERI BIJADŽI 1990: 35).

У раду који смо поделили на неколико целина најпре ћемо изнети основне податке о дијалогу као прозном жанру који је Галилеј изабрао за представљање својих научних мисли, ставова и сазнања. У другом делу ћемо говорити о структури и теми дела Дијалог о два главна система свеma које чини корпус емпиријског дела нашег рада. У оквиру треће целине, после краћег увида у основне особине језика којим је Галилеј написао своје научно дело, детаљније ћемо обрадити уметнуте реченице. Сматрамо да је уметнуте реченице неопходно с посебном пажњом посматрати унутар сложене синтаксичке структуре овог дела, јер се и сам писац одлучио за њихову фреквентну употребу. Анализа ће обухватити класификацију уметнутих реченица према врсти комуникативних функција које обављају, уз навођење одговарајућих примера. Рад ће се завршити закључним разматрањима о језичко-комуникативном значају уметнутих реченица, могућностима даљег истраживања на ову тему, али и снажној повезаности Галилејевог језика науке и данашњег научног дискурса.

\section{2. Дијалог као жанр научне прозе}

Научну револуцију, која је свој врхунац доживела у XVII и даље у XVIII веку, обележило је на првом месту другачије конципирање света, опсервирање природе и универзума са становишта разума а не вере, коришћење методологије засноване на емпирији и вредновању доказа, а не само на посматрању појава. Поред увођења оваквих концептуалних промена, прихватање нове науке зависило је и од нових прозних облика

3 Ширу анализу синтаксе и лексике Галилејевог дела Дијалог о два главна система све$m a$, која садржи и неке од делова који се појављују у теоријским целинама овог рада, ауторка Дрљевић је приказала у својој монографији Италијански језик науке и струке од средњег века до данас (у штампи). 
односно жанрова, по чијим се правилима тај садржај исказивао и даље преносио (DARDANO 1994: 534). Овоме у прилог говори и Алтијери Бијаџи која је темељно истражила условљавање између културолошког и идеолошког контекста с једне стране, пишчевог вођења рачуна о различитим групама прималаца и, коначно, индивидуалног избора научника да своје дело напише у једном, а не у другом прозном жанру (ALTIJERI BIJADŽI 1984: 891-947).

Галилеј је писао у свим прозним жанровима. Реч је о жанровима који, како прецизира Буркхарт (Burckhardt), представљају са више или мање одступања репродукцију антике. Овде спадају расправе (трактати) у непосредном облику, разговори (ит. discorsi), дијалози и епистоле (BURKHART 1991: 1127-133). За све наведене жанрове, кроз које је овај великан у писаној форми исказао своје виђење науке и представио научна достигнућа, вековима су, поред саме научне јавности, заинтересовани и стручњаци за проучавање италијанског језика, посебно језика науке. Активно се изучавају: текстуална структура, синтаксичка организација периода и терминологија из области физике, коју је Галилеј у великој мери кодификовао.

Поред дела које је тема нашег рада, Галилеј је још једно своје дело написао у форми дијалога. Изузетну језичку виталност овог жанра научник је искористио за описивање дијалектичког процеса, на коме се, између осталог, и заснивала нова научна метода. За разлику од античког дијалога, у овој форми у периоду хуманизма и ренесансе учесници су имали имена, а обично је један од учесника заступао ставове самог писца. Кроз смењивање турнуса различитих учесника у дијалогу износе се идеје, претпоставке и размишљања, супротстављају и доказују научне теорије (DARDANO 1994: 534; KORTELACO 2014: 40). Оваква структура допринела је лакшем читању научног садржаја, ублажујући његову природну сувопарност и традиционалну херметичност.

Дијалог, као жанр научне прозе, наилази на практичну примену и у наредним вековима. Структура и ток расправе који се неговао у дијалогу, са честим дигресијама и понављањима, пренели су се и у језичку праксу на академије, а од XVIII века и на дворове, међу припаднике високог сталежа, жељне нових знања (DARDANO 1994: 534, 537).

\section{3. О делу Дијалог о два главна система света}

Галилеј је већ на почетку свог стваралаштва са научном радозналошћу почео да се бави Коперниковом теоријом, коју су црква и католичка доктрина оштро осудиле и одбациле. Више деценија је сакупљао доказе који би потврдили ново уређење космоса, да би коначно 1632. године објавио дело Дијалог о два главна система света и у њему се, кроз 
аргументовану дискусију између различитих учесника, заузео и ангажовао у изношењу научних доказа који би потврдили Коперникову тезу о хелиоцентричном уређењу космоса.

У дијалогу се разговор води између тројице учесника: Салвијатија (Filippo Salviati), Сагреда (Giovanni Francesco Sagredo) и Симплича (Simplicio).

Фирентински научник Салвијати био је Галилејев пријатељ, и у делу заступа Галилејеве научне ставове, доказујући претпоставку о новом уређењу космоса, супротстављајући је аристотеловско-птоломејској геоцентричној космологији Симплича. О томе која се историјска личност крије иза овог учесника постоји неколико претпоставки. Без сумње он је типични представник аристотеловске перипатетичне филозофске школе и име му је вероватно преузето од Симплича из Чиличе (Simplicio di Cilicia) чувеног коментатора Аристотеловог дела (FLORA 1959: 16). Трећи учесник у дијалогу, Сегредо, јесте још један Галилејев пријатељ венецијански племић и оштри противник цензуре коју је спроводила црква. Његова улога је веома битна у смислу структурирања дидактичке природе овог дела, јер он је истовремено модератор између два научна виђења света али и неко ко, иако веома образован, не припада ниједној филозофској школи и није довољно стручан попут својих саговорника. Сегредо је тај који ће од својих саговорника често тражити додатна објашњења појединих научних исказа и тврдњи.

Већ због саме овакве поделе учесника у дијалогу Галилеј успева да комуницира са различитим припадницима читалачке публике: стручњацима с једне стране, али и не толико стручном, рекли бисмо полустручном публиком, с друге стране.

Дело је подељено према традиционалним начелима филозофских жанрова на посвету мецени - у Галилејевом случају реч је о Великом тосканском војводи Козиму Медичију (Cosimo de' Medici), посвету читаоцу (ког Галилеј назива discreto lettore ${ }^{4}$ и, у конкретном случају, на четири дана током којих се води расправа. Током првог дана се дискутује о кључном начелу аристотеловске доктрине - природи и суштини небеске материје и њеним разликама у односу на земаљску. Централне теме расправе другог дана односе се на дневно кретање и ротацију Земље око своје осе, док се трећег дана саговорници суштински посвећују разговорима који су у вези са годишњим кретањем Земље. Трећег дана се уводи и теза о револуцији Земље око Сунца, те наводе, од стране Салвијатија, докази против Птоломејеве традиционално прихваћене теорије о уређењу космоса. Четврти дан је посвећен питању плиме и осеке и повезаности њиховог смењивања са кретањем Земље. Кохерентност структуре постигнута је

4 discreto lettore - скромни читалац (Флора 1959: 37). 
кроз образац анафоричког понављања и катафоричког антиципирања на почетку сваког наредног дана расправе. Ова два елемента присутна су и у далеко старијим научним делима написаним италијанским народним језиком (ALTIJERI BIJADŽI 1990: 30-31; LIBRANDI 2013: 65-67), и то нам, између осталог, потврђује однос који Галилеј одржава са традицијом.

\section{4. Опште особине Галилејевог научног језика}

Галилејев избор народног језика значајан је, како због иновација које је унео у језик науке, тако и због јаке комуникативне намере писца да се, осим стручњацима одређених области истраживања, обрати и ширем образованом и истовремено моћном слоју грађана који су били у стању да помогну његова истраживања. Галилејев народни језик (тоскански) представља спој негованог и нормираног књижевног језика, насталог на основама Бембовог језичког модела (ит. il volgare letterario-bembesco), истовремено прилагођеног функцијама научног садржаја и потребама специфичних корисника. Реч је о елегантном стилу јасног израза, али и, како наводи Кортелацо (2014: 43), веће живости, посебно у односу на латински језик који научник, свакако, активно наставља да користи.

Галилеј се с посебном пажњом и преданошћу посветио дефинисању и прецизирању појединих научних појава и феномена, везујући их потом за подједнако јасно дефинисане термине. Наиме, дао је несумњиву предност речима из општег језика и, претходно их очистивши од евентуалних колоквијалних наноса, проширио њихову семантику и укључио их у глосаре техничких термина на пољу физике, астрономије, математике и геометрије (MILJORINI у ALTIJERI BIJADŽI 1965: V).

На плану синтаксе Галилејев допринос огледа се у повећању фреквентности појављивања елемената логичке организације мисли, што је од суштинског значаја за разумевање научног дискурса. Ствара се тако, како потврђује и ауторка Фјорентино (FIORENTINO 1998: 74), принцип језичке кохеренције као једна од основних потпора кохеренцији научних аргумената. Ови елементи тичу се у првом реду редукције улоге глагола средствима од којих су нека типична за стварање номиналног стила попут: коришћења специфичних именица или именичких синтагми на уштрб глагола који су семантички ослабљени и често сведени на малобројне генеричке представнике ове врсте, наглашене употребе партиципа (садашњег и прошлог), честе употреба пасива и поимениченог инфинитива. У овом делу уочљиви су, на многим местима, веома комплексни и дугачки синтаксички периоди, чију кохезију писац успоставља и одржава служећи се средствима као што су: понављање апозиције, употреба посебних лексичких јединица (у виду синонима или изведеница), навођење показних заменица questo и quello или, већ поменутих анафора и ка- 
тафора, те из ранијих векова преузетих елемената тематске подељености, коју можемо посматрати како са становишта синтаксе, тако и са становишта пишчевог стила. Коначно, уметнуте реченице, које ћемо детаљније представити у делу 3.1., представљају, по нашем мишљењу, упечатљиво синтаксичко средство, путем ког писац успева да свом делу да оригиналност, пре свега са аспекта комуникативности.

На основу овог кратког прегледа језичких елемената присутних у делу, остаје нам да закључимо, и тиме се сложимо са бројним италијанским ауторима (ALTIJERI BIJADŽI 1965; DARDANO 1994; LIBRANDI 2013), да је Галилеј поставио темеље италијанске научне прозе - новог и другачијег научног дискурса који се развија истовремено са новим научним методама.

4.1. Уметнуте реченице као синтаксички елемент постизања комуникације

Број уметнутих реченица у Галилејевом делу заиста је велик, а једна од њихових функција, према нашем мишљењу и доминантна, јесте комуникативне природе и остварује се на неколико паралелних нивоа у тексту. У великом броју случајева писац их у текст умеће на нетипичан начин, смештајући их у заграде, повећавајући на тај начин њихову видљивост и отворену комуникативну намеру. Не руши, притом, ни на који начин кохеренцију или кохезију текста. Доприноси, штавише, виталности и живости дијалога.

Више је, како смо већ наговестили, нивоа испољавања комуникативних намера писца и генерално успостављања контакта са читаоцима. У прегледу који следи уметнуте реченице подељене су на основу различитих комуникативних функција, путем којих писац јасно, кроз учеснике у дијалогу, остварује везу са читаоцима. Навешћемо, за сваку од функција, и одговарајући број примера 5 . Оваквих је уметнутих реченица далеко већи број у приказаном делу, а ми ћемо за потребе овог рада, услед ограниченог простора, навести само неке од њих.

1. Уметнуте реченице у функцији коментарисања појединих лексема:

a) ...ma quello di che vi è maggior frequenza, sono alcuni argini (userò questo nome, per non me ne sovvenir altro che più gli rappresenti) ${ }^{6}$ assai rilevati... (стр. 98)

b) ...non abbia ancora avvertita la risposta, ond'io voglio tentar di

5 Сви примери су преузети из издања које је приредио FLORA (1959).

6 Уметнуте реченице у самом делу нису наведене у курзиву. Аутор овог рада користи курзив како би додатно нагласио овај синтаксички елемент. 
cavargliela (come si dice) di bocca (стр. 118)

c) ....al più dunque che potesse accadere sarebbe che tali angoli e (per cosi dire) escrescenze si corrompessero (стр. 122)

d) ...voi dicevi così per tentarmi e (come si dice dal vulgo) per iscalzarmi... (cтp. 186)

e) E di qui nasce la soluzione di quell'effetto ...cioè d'ingannar l'avversario col trinciar (che tale è il lor termine) la palla... (стр. 201)

f) ...ma perché ho veduto che il signor Simplicio prende gusto di certe arguzie da chiappar (come si dice) il compagno... (стр. 215)

g) Potrò dunque io questa volta farvi a tutti due (come si dice) il maestro addosso... (стр. 295)

h) Concludiamo per tanto, che la diversità di apparenza (la quale con termine proprio dellarte potremo chiamar parallasse delle stelle fisse) è maggiore e minore...(стр. 441)

i) ... sì che i filamenti (per cosi dire) che collegano i due ferri...(стр. 465)

2. Уметнуте реченице у функцији дефинисања, додатног појашњавања или именовања одређених појмова:

a) ...essendo de i corpi naturali, altri semplici ed altri composti di quelli (e chiama corpi semplici quelli che hanno da natura principio di moto, come il fuoco e la terra) (стр. 47)

b) ...partendosi dallo stato della quiete (che è il grado di infinita tardità di moto), non ci è ragione nessuna per... (стр. 53)

c) ...e però il tempo per $\mathrm{CT}$ al tempo per $\mathrm{CB}$ (che gli è eguale) avrò maggior proporzione... (стр. 59)

d) ...e quanto all'altra macchia (perché l’è più vicina alla circonferenza), tal mutazione importa... (стр. 102)

e) ...dalla asprezza e scabrosità della sua superficie...cioè dall'essere atta a ricevere (come veggiamo tra noi nelle gemme più dure) un pulimento... (стр. 105)

f) ...cioè le montagne più delle pianure, e questo per la lor solidità e durezza (ché se fusser di materia fluida si spianerebbero), così il veder noi... (стр. 134)

g) ...la superficie del mare, ... sì come apparirebbe egualissima (trattone le isole e gli scogli) così apparirebbe men chiara che quella della terra... (стр. 135)

h) ...ma le medesime stelle andranno variando suoi cerchi e sue velocità (e sarà il quinto inconveniente), avvengaché quelle che... (стр. 158)

i) ...l'orizonte si va sempre abbassando verso levante ed alzandosi da ponente (che però ci appariscono le stelle orientali alzarsi, ele occidentali abbassarsi), adunque il bersaglio orientale... (стр. 166) 
j) Tutti i mobili ... par che restino indietro...eccettuata la prima sfera (cioè il primo mobile)... (стр. 176)

k) ...la diminuzion della medesima velocità dependente dalla diminuzion della gravità del mobile (che era la seconda causa) si faccia essa ancora con la medesima proporzione (стр. 244)

1)...e da quel maggiore accrescimento, cioè dall'eccesso dell'accrescimento...sopra l'accrescimento dell'altezza polare (che si chiama differenza di parallasse), si calcola (стр. 332)

$\mathrm{m})$...ed in quello si volga in se stesso non intorno all'asse di essa eclittica (che sarebbe l'asse del movimento annuo della Terra)...(стр. 402)

3. Уметнуте реченице у функцији пишчевог коментарисања ненаучних тема:

a) ...e pur che lo scrittore stesso non sia (come molti ce ne sono) di quelli che scrivono quel che non intendono ... (стр. 114)

b) All'incontro, di quanti io abbia interrogati de i Peripatetici e Tolemaici (che per curiosità ne ho interrogati molti), quale studio abbiano fatto nel libro del Copernico (стр. 167)

c) Di qui parmi (discorrendo con una certa convenienza) di poter credere... (стр. 271)

d) Posto per ora che l'acqua e il fuoco sien contrarii, come anche l'aria e la terra (che pur ci sarebbe da dire assai), il più che da questo ne possa seguire... (стр. 283)

e) ...e finalmente maccorsi della mia semplicità (ma però scusabile) nell'ammetter per vero quello che è falsissimo... (стр. 295)

f) ...e poi fabbricati i discorsi umani abili a poter capire (ma però con fatica grande) alcuna cosa... (стр. 309)

g) E per non aver a ripigliar più la parte di questo oppositore, sentite quel ch'ei (Copernico) produce contro al Keplero (co 'l quale ei disputa), in propostito di quello che ... (стр. 313)

h) ...ed intanto il signor Sagredo condoni al signor Simplicio ed a me il tediarlo forse un po' troppo, mentre con soverchio circuito di parole (soverchio, dico, alla sua velocissima apprensiva) anderò cercando di far palese cosa... (стр. 335)

i) Ma per liberare in tutto e per tutto questo autore da queste infelicissime mendicità, sappia (già che si vede che egli non ha molta nell'uso de gli strumenti astronomici) che ne i lati... (стр. 371)

4. Уметнуте реченице у функцији потврђивања исказа кроз сопствене ставове или мишљења ауторитета: 
a) ...non sarà forse se non ben fatto, prima che si accresca il cumulo de i dubbi, vedere se per avventura (si come io stimo) incamminandoci per altra strada...(стр. 51)

b) ...e trovato (come in effetto è) che Giove si muove più velocemente, conviene che... Giove sia sceso più che Saturno (стр. 62)

c) ...veggendo ed ammirando la grandezza e la bellezza del mondo e del suo Facitore e Rettore, e con encomii continui cantando la Sua gloria, ed in somma (che è quello che io intendo) facendo quello... (стр. 97)

d) Confessate dunque, per la vostra medesima concessione (ed averete anco altri filosofi per compagni), grandissima affinitò esser tra la Terra e la Luna (стр. 134)

e) ...che credete voi che ella facesse? non credete voi (si come credo io) che ella stesse ferma? (стр. 185)

f) Quante proposizioni ho io notate in Aristotile (intendendo sempre nella filosofia naturale), che sono non pur false, ma... (стр. 193)

g) ... già che il signnor Simplicio resta (per quanto io mi creda) ben capace della nullità... (стр. 196)

h) ...ed oltr'a ciò il tirar (com'io credo) non con una sola palla, ma con buon numero di palline... (стр. 221)

i) Or guardiamo nella tavola de gli archi e corde (che ecco qui appunto il libro del Copernico), qual parte è la corda... (стр. 223)

j) Come le due rette sien maggiori della A B (si come è noto per Euclide), tuttavia... (стр. 248)

k) ...potendo esser (come afferma il Copernico) che l'immensa lontananza della sfera (стр. 443)

1) .... quando il pezzo sia a perpendicolo e la Terra si muova, la palla non solo non avrebbe a ricader, come vuole Aristotile e Ticone, lontana dal pezzo verso occidente, ma né anco, come volete voi, sopra il pezzo... (стр. 217)

5. Уметнуте реченице са глаголима notare (приметити) у императиву и vedere (видети) у функцији успостављања приснијег односа са читаоцем и скретања пажње на значај одређеног сегмента у дијалогу:

a) Quello che si genera, si fa da un contrario in qualche subietto...sì che (notate bene) la corruzione e generazione non è se non ne i contrari... (стр. 72)

b) Ma perché (notate bene) la lontananza del firmamento in relazione alla piccolezza della Terra, come gia sè detto, si reputa come infinita ... (стр. 337)

c) E perché (come vedete) l'appressamento e discostamento de' tre superiori vien misurato...(стр. 379) 
6. Уметнуте реченице у функцији анафоре или катафоре:

a) ...e perché (come dicevamo) i gradi di velocità acquistati ne i punti $\mathrm{B}$, A... (стр. 61)

b) ..il medesimo Aristotile antepone (come più volte sè detto) l'esperienze sensate a tutti i costi; (стр. 86)

c) E' che, se la Terra (come bene avete notato) non vede altro che la metà della Luna... (стр. 100)

d) ...questa (come si è detto) per aria non spigne punto...(стр. 200)

e) ...e dovendo (come già si è concluso) continuar la pall ail suo moto per l'aria...(стр. 217)

f) Prima cerchiamo, così (come ho detto) a un di presso... (стр. 223)

g) ...che non vi bisogna chiamar principio interno né esterno (come a suo luogo dimostrerò) dal quale, come da causa, venga prodotto (стр. 307)

7. Уметнуте реченице у функцији пишчевог ограђивања или преузимања одговорности:

a) Io (non voglio nascondere l'error mio) concorsi nel medesimo parere... (стр. 294)

b) Ma (siami permesso d'usar questo termine) la pusillanimità de gl'ingegni comuni è giunta a segno...(стр. 457)

\section{5. Закључна разматрања}

Дело Дијалог о два главна система света италијанског научника Галилеа Галилеја представља оригиналан допринос новој научној мисли која се развијала у XVII и XVIII веку. Поред несумњивог значаја које ово дело има у научној заједници на међународном нивоу, из перспективе језика, а посебно историјског развоја италијанског језика науке, оно представља иновацију у сваком смислу. Бројни италијански аутори већ дуги низ година анализирају језик Галилејеве научне прозе, сведочећи о његовој посебности и подвлачећи, управо на овом примеру, потенцијал народног језика за исказивање научног знања, а тиме и за дифузију саме науке.

У нашем раду посебно смо обрадили уметнуте реченице које су бројне унутар сложене пишчеве синтаксе и сагледали их с аспекта комуникативне функционалности. Показали смо, кроз део примера преузетих из поменутог научног дела, на који начин Галилеј, служећи се уметнутим реченицама, у скоро свим случајевима графички издвојеним у заградама, 
комуницира са својим читаоцима. Нивои комуникације и природа порука, које научник упућује својим читаоцима, разноврсни су: преко пружања објашњења научних концепата и специфичних термина, исказивања сопствених ставова или позивања на признате ауторитете у дотадашњој науци, до употребе анафоре или катафоре, као начина одржавања кохерентности текста типичног за научни диксурс и пре Галилеја, али и за савремени научни стил. Научник са читаоцима успоставља присан однос, иако износи комплексне научне теорије, трудећи се да његово дело буде максимално разумљиво и делу публике који чине образовани, али полустручни читаоци. У том смислу ово дело представља нов, посве иновативан приступ у представљању научних садржаја.

Галилејев језик савремен је и за данашњег читаоца научних дела јер писац фреквентно употребљава типичне елементе модерног језика науке у ком преовлађује номинални стил, као кључно средство у постизању тематизације текста и изношења научних чињеница.

\section{Цитирана литература}

ALTIERI BIAGI, Maria Luisa. Galileo e la terminologia tecnico - scientifica. Firenze: Olschki, 1965.

ALTIERI BIAGI, Maria Luisa. „Le forme della comunicazione scientifica”. U: Asor Rosa, A. (ur.). Letteratura italiana. Le forme del testo, II. La prosa. Torino: Einaudi, 1984, Vol. 3, 891-947.

BURKHART, Jakob. Kultura Renesanse u Italiji. Bazel 1860. Beograd: Dereta, 1991. [orig.] Burchhardt, Jacob. Die Kultur der Renaissance in Italien. Basel 1860. Beograd: Dereta, 1991.

CORTELAZZO, Michele. „Le lingue di Galileo Galilei”. Il Nuovo Saggiatore, Bollettino della Società italiana di fisica. Anno XXX, N. 5-6 (2014): str. 38-44<https:// www.ilnuovosaggiatore.sif.it>13. 8. 2019.

DARDANO, Maurizio. „I linguaggi scientifici”. U: Serianni, L., Trifone, P. (ur.). Storia della lingua italiana II. Scritto e parlato. Torino: Einaudi, 1994, 497-551.

DRLJEVIĆ, Jelena. O italijanskom jeziku nauke i struke od srednjeg veka do danas. Beograd: Filološki fakultet. (u štampi)

FIORENTINO, Giuliana. „Peculiarità sintattiche della prosa scientifica: il caso di Galilei". Revista Española de Linguistica, 28, (1998): 73-88.

GIUDICE, F. La rivoluzione scientifica e le origini della scienza moderna. <http:// ppp.unipv.it/PagesIt/StoriaScienza/PDF/rivscient.PDF> 1. 10. 2020.

LIBRANDI, Rita. „Dante e la lingua della scienza”. U: Tavoni, M. (ur.). Letture classensi. Dante e la lingua italiana. Ravenna: Longo Editore, 2013, Vol. 41, 61-88.

HRNJEZ, Saša. Galilej Dijalog o dva glavna Sistema sveta. Novi Sad: Akademska knjiga, 2012. 


\section{Извори}

FLORA 1959: FLORA, Ferdinando. Galilei, G. Dialogo sopra i due massimi sistemi del mondo. Volume primo. Milano: Rizzoli Editore, 1959.

FLORA 1959: FLORA, Ferdinando. Galilei, G. Dialogo sopra i due massimi sistemi del mondo. Volume secondo. Milano: Rizzoli Editore, 1959.

Jelena Drljević

\section{A COMMUNICATIVE FUNCTION OF EMBEDDED CLAUSES IN GALILEO GALILEI'S DIALOGO SOPRA I DUE MASSIMI SISTEMI DEL MONDO}

The paper emphasises a communicative function of embedded clauses largely used in Dialogo sopra i due massimi sistemi del mondo by Italian scientist Galileo Galilei. In addition to having enormous significance for science, this work is the epitome of using a vernacular in order to present and further transmit scientific knowledge. In this respect, syntax is a particularly notable language level. To a large extent, the author reorganises and codifies syntax, increasing the frequency of certain elements rarely used before the $17^{\text {th }}$ century. The aim of the paper is to point out that a syntactic element, that is to say the embedded clause, contributes to a communicative connection between the scientist and his audience. In this way, it also directly influences the comprehension of the scientific content. The research on the functions of this specific syntactic element will be carried out in a wider context of dialogue as a genre. It is the dynamism of this genre that serves as a tool for introducing Galilei's own scientific views and knowledge, which means modern views and knowledge at the same time. The author continues but also enriches the ancient prose form, especially suitable for language experiments.

Keywords: embedded clausses, Galileo Galilei, dialogue, syntax, communicative function 